\title{
Differential Effect of Cyclosporin A on Activation Signaling in Human T Cell Lines
}

\author{
Bemhard Manger, Kenneth J. Hardy, Arthur Weiss, and John D. Stobo \\ Howard Hughes Medical Institute and Department of Medicine, University of .California/San Francisco, California 94143
}

\begin{abstract}
Different $\mathbf{T}$ cell lines, which can be induced to secrete interleukin 2 (IL-2) in vitro, were used to dissect the effect of cyclosporin A (CsA). The T leukemia cell Jurkat requires an increase in cytoplasmic calcium concentration $\left(\left[\mathrm{Ca}^{++}\right]\right)$and phorbol myristate acetate (PMA) for the induction of IL-2 production, which is completely blocked by CsA. Another T cell line, HUT 78, also produces $\mathrm{IL-2}$ in response to a rise in $\left[\mathrm{Ca}^{++}\right]$and PMA; however, in HUT 78, PMA alone induces low levels of IL-2 production that is not blocked by CsA. After treatment with 5azacytidine, HUT 78 cells produced maximal levels of IL-2 in response to PMA alone without requiring $\left[\mathrm{Ca}^{++} \mathbf{b}\right.$ increasing stimuli. In these cells no inhibitory effect of $\mathrm{CsA}$ on PMA-induced activation could be demonstrated. In addition, $\mathrm{CsA}$ does not inhibit PMA-induced translocation of protein kinase $C$. These data suggest that CsA does not globally inhibit IL-2 gene expression, but rather interferes with signaling events of $T$ cell activation.
\end{abstract}

\section{Introduction}

The fungal metabolite cyclosporin A $(\operatorname{Cs} A)^{1}$ has found widespread use as an immunosuppressive agent in human organ transplantation. Unlike other immunosuppressants, CsA has inhibitory effects primarily on the activation of $\mathrm{T}$ lymphocytes (1-3). It has been demonstrated that CsA inhibits the production of interleukin 2 (IL-2) and interferon- $\gamma$ (IFN- $\gamma$ ) by T cells (46). It also reduces the expression of HLA-DR antigens and transferrin receptors on stimulated $T$ cells; it has no effect, however, on the induction of IL-2 receptor expression $(7,8)$.

We have recently studied the human $T$ cell leukemia line Jurkat as a model for $T$ cell activation. Two stimuli are required for the induction of IL-2 secretion by Jurkat. One stimulus is represented by phytohemagglutinin (PHA) or antibodies against the T3/antigen receptor complex that lead to a rapid increase in cytoplasmic-free calcium $\left(\left[\mathrm{Ca}^{++}\right]_{\mathrm{i}}\right)$. Thus, these stimuli can be bypassed by calcium ionophores. The other stimulus is provided by phorbol myristate acetate (PMA) $(9,10)$. No substantial

Portions of this work were presented at the 70th Annual Meeting of the Federation of American Societies for Experimental Biology, St. Louis, MO, 1986; and have been published in abstract form, 1986. Fed. Proc. 45:505.

Address correspondence to Dr. Manger, Department of Medicine, University of California, San Francisco. Dr. Stobo's present address is Johns Hopkins University, Department of Medicine, Baltimore, MD.

Received for publication 15 November 1985.

1. Abbreviations used in this paper: AZA, 5-azacytidine; $\left[\mathrm{Ca}^{++}\right]_{\mathrm{i}}$, cytoplasmic-free calcium concentration; CsA, cyclosporin A; IFN- $\gamma$, interferon- $\gamma$; IL-2, interleukin 2; PHA, phytohemagglutinin; pkC, protein kinase C; PMA, phorbol myristate acetate.

J. Clin. Invest.

(C) The American Society for Clinical Investigation, Inc. $0021-9738 / 86 / 05 / 1501 / 06 \quad \$ 1.00$

Volume 77, May 1986, 1501-1506
IL-2 production can be observed with either stimulus alone. Recent studies from different groups have demonstrated that the IL-2 production by Jurkat can be completely and specifically blocked by CsA at a pretranslational level $(11,12)$.

Another human T cell line, HUT 78, represents an activated $T$ cell, as evidenced by its surface expression of the activation markers HLA-DR and the IL-2 receptor. HUT 78 also produces IL-2 in vitro in response to the same stimuli as Jurkat (13). However, in contrast to Jurkat, HUT 78 produces low levels of IL-2 upon stimulation with PMA only. To further dissect mechanisms of activation signaling for the expression of the IL-2 gene, we investigated the effects of the nucleoside analogue 5-azacytidine (AZA) on HUT 78. AZA treatment can provide one signal, which in conjunction with a second stimulus leads to the expression of various inducible eukaryotic genes (mouse metallothionein, chicken embryonic globin, and human HLA-DR alpha) (14-16). After HUT 78 was treated with AZA, the requirement for $\left[\mathrm{Ca}^{++}\right]_{\mathrm{i}}$ increasing stimuli, such as lectins, $\mathrm{T} 3$ antibodies, or $\mathrm{Ca}^{++}$ionophore, could be overcome. AZA-treated HUT 78 cells produced maximal amounts of IL-2 in response to PMA only. One subclone, designated D4, was obtained from AZA-treated HUT 78, which maintained this functional characteristic in culture for several months.

The cell lines Jurkat, HUT 78, and D4 were used in this study to investigate the effects of CsA on the signaling of activation in $\mathrm{T}$ cells. We demonstrate that CsA treatment does not always lead to a global blockade of IL-2 gene expression, as has been suggested using Jurkat cells (11). Using HUT 78 and D4, we demonstrate that the CsA-sensitive step is located in the signaling pathway of $\mathrm{T}$ cell activation. It appears that in HUT 78 and D4 the pathway regulated by PMA alone is not affected by CsA. CsA exerts its inhibitory effect upon the activation pathway regulated by either $\left[\mathrm{Ca}^{++}\right]_{i}$ alone or in combination with PMA along a common final pathway.

\section{Methods}

Cells. The T cell lines HUT 78 and E6-1, an IL-2-producing clone of Jurkat-FHCRC (Fred Hutchinson Cancer Research Center, Seattle, WA), were obtained from Dr. R. Miller (Becton-Dickinson \& Co., Sunnyvale, CA) and Dr. K. Smith (Department of Medicine, Dartmouth Medical School, Hanover, NH), respectively, and passaged in RPMI 1640 with $10 \%$ fetal calf serum. The IL-2-dependent mouse T cell line CTLL-20 was obtained from Dr. F. Fitch (Department of Microbiology and Pathology, University of Chicago, IL) and maintained in IL-2 containing medium as described (10).

Stimulation of $T$ cell lines and determination of IL-2 activity. $T$ cells were stimulated at $1 \times 10^{6} / \mathrm{ml}$ in 96-well flat bottom plates (Flow Laboratories, Inc., McLean, VA) for $24 \mathrm{~h}$. The following concentrations of stimulating agents were used: Phytohemagglutinin (PHA; BurroughsWellcome, Research Triangle Park, NC) at $1 \mu \mathrm{g} / \mathrm{ml}$; OKT3 antibody (Ortho Pharmaceutical Corp., Raritan, NJ) at a dilution of 1:400; ionomycin (a gift from Squibb Corp., Princeton, NJ) at $1 \mu \mathrm{M}$; PMA (Sigma Chemical Co., St. Louis, MO) at $50 \mathrm{ng} / \mathrm{ml}$ for Jurkat and $25 \mathrm{ng} / \mathrm{ml}$ for HUT 78 and D4 cells. For inhibition of IL-2 production, $1 \mu \mathrm{g} / \mathrm{ml} \mathrm{CsA}$ was added simultaneously with the various stimulants and was present throughout the culture. IL-2 activity in cell-free supernatants was determined using the CTLL-20 line according to previously described methods 
$(10,17)$. Neither CsA, nor any of the stimulants, had any influence upon the IL-2-induced proliferation rate of CTLL-20 cells. The lower limit for the detection of IL-2 production in this assay was $2 \mathrm{U} / \mathrm{ml}$.

$A Z A$ treatment and subcloning of HUT $78.4 \times 10^{6}$ HUT 78 cells were incubated in $10 \mathrm{ml}$ cell culture medium containing $3 \mu \mathrm{M}$ of AZA. After $48 \mathrm{~h}, 10 \mathrm{ml}$ of a $6-\mu \mathrm{M}$ solution of fresh AZA was added and cells were incubated for an additional period of $24 \mathrm{~h}$. Recovery of cells after this treatment was $30-60 \%$ of control cultures without AZA. The percentage of viable cells by trypan blue staining was always $>95 \%$. Cells were washed three times before they were stimulated for IL-2 production.

The clone D4 was obtained by limiting dilution of HUT 78 cells after AZA treatment as described above. A total of 11 clones were tested for their IL-2 production in response to PHA $(1 \mu \mathrm{g} / \mathrm{ml})$ plus PMA (25 $\mathrm{ng} / \mathrm{ml})$ versus IL-2 production in response to PMA $(25 \mathrm{ng} / \mathrm{ml})$ only. Clone D4 produced virtually identical amounts of IL-2 activity with one or two stimuli.

Analysis of RNA transcripts. Total cellular RNA was purified using guanidium hydrochloride (18). It was analyzed for the content of IL-2specific sequences by Northern blot hybridization to an IL-2 cDNA probe nick-translated to $\sim 2 \times 10^{8} \mathrm{cpm} / \mu \mathrm{g}$ with ${ }^{32} \mathrm{P} .40 \mu \mathrm{g}$ of total cellular RNA was applied to each lane before electrophoresis and blotting. In parallel, duplicate RNA samples immobilized on nylon filters were hybridized to actin as a positive control. The hybridization signals using actin cDNA showed virtually equal intensity for all samples.

Protein kinase $C(p k C)$ translocation assay. To investigate possible effects of CsA on PMA-induced translocation of pkC, Jurkat cells were incubated for $12 \mathrm{~h}$ in culture medium containing $1 \mu \mathrm{g} / \mathrm{ml} \mathrm{CsA}$. Thereafter, PMA was added to the media to a final concentration of $50 \mathrm{ng} / \mathrm{ml}$ and cells were incubated for $20 \mathrm{~min}$ at $37^{\circ} \mathrm{C}$. Cells $\left(1 \times 10^{7}\right)$ were washed twice in $\mathrm{Ca}^{++}$- and $\mathrm{Mg}^{++}$-free phosphate-buffered saline and thereafter lysed in $100 \mu$ l distilled water. The lysate was reconstituted with $2 \mathrm{ml}$ buffer ( $20 \mathrm{mM}$ Tris, pH 7.5, $0.33 \mathrm{M}$ sucrose, $2 \mathrm{mM}$ EDTA, $0.5 \mathrm{mM}$ EGTA, and $2 \mathrm{mM}$ phenylmethylsulfonylfluoride). Cytosol and particulate fractions were separated by centrifugation at $100,000 \mathrm{~g}$ for $30 \mathrm{~min}$. The pellets were gently agitated for $30 \mathrm{~min}$ in buffer containing $1 \%$ NP40 and after that centrifuged at $12,000 \mathrm{rpm}$ for $10 \mathrm{~min}$. Cytosol and solubilized membrane fractions were passed through a 1-ml column of DE52. Columns were washed with $5 \mathrm{ml}$ of buffer without sucrose followed by $0.5 \mathrm{ml}$ of $50 \mathrm{mM} \mathrm{NaCl} .1 .5 \mathrm{ml}$ of $100 \mathrm{mM} \mathrm{NaCl}$ eluate was collected. As demonstrated by others, all pkC activity can be detected in this fraction (19). The activity of the calcium-activated phospholipid-dependent pkC was determined in aliquots of $50 \mu \mathrm{l}$ as transfer of ${ }^{32} \mathrm{P}$ from $\left[\gamma^{32} \mathrm{P}\right] \mathrm{PTP}$ to histone III-S (Sigma Chemical Co.) as described in detail (20). The specific pkC activity (after subtraction of background activity in the absence of phospholipids) is given as picomoles ${ }^{32} \mathrm{P}$-incorporation into histone within $3 \mathrm{~min}$.

\section{Results}

Inhibition of IL-2 production in Jurkat and HUT 78 cells by $C s A$. We have recently demonstrated a two-signal requirement for the activation of the $T$ cell line Jurkat $(9,10)$. The first signal can be provided by the mitogen PHA or T3/antigen receptor complex antibodies. These lead to an increase in cytoplasmicfree calcium that can be bypassed by calcium ionophores ( 9 , 21). To induce substantial IL-2 production by Jurkat, however, a second signal is necessary which is represented by the phorbol ester PMA. As shown in Table I, and as previously reported (12), the presence of $1 \mu \mathrm{g} / \mathrm{ml} \mathrm{CsA}$ throughout the 24-h culture completely abrogates the IL-2 production by Jurkat.

Another T cell line, HUT 78, can also be induced to produce IL-2 by a combination of the above listed stimuli (Table I). Compared with Jurkat, HUT 78 represents phenotypically a more activated $\mathrm{T}$ cell, evidenced by the display of activation antigens Tac and Ia (13). A functional difference between HUT 78 and Jurkat is that HUT 78 produces small amounts of IL-2 activity in response to stimulation with PMA only. This low but
Table I. Differential Inhibitory Effect of Cyclosporin on the IL-2 Production by Jurkat and HUT 78

\begin{tabular}{|c|c|c|c|c|}
\hline \multirow[b]{2}{*}{ Stimulants } & \multicolumn{2}{|l|}{ Jurkat } & \multicolumn{2}{|c|}{ HUT 78} \\
\hline & $-\mathrm{CsA}$ & $+\mathrm{CsA}$ & $-\mathrm{CsA}$ & $+\operatorname{CsA}$ \\
\hline 0 & $<2^{*}$ & $<2$ & $<2$ & $<2$ \\
\hline PMA & $<2$ & $<2$ & 6.2 & 5.8 \\
\hline PHA & 2.8 & $<2$ & $<2$ & $<2$ \\
\hline PHA + PMA & 48.0 & $<2$ & 31.0 & 6.5 \\
\hline Anti-T3 & $<2$ & $<2$ & $<2$ & $<2$ \\
\hline Anti-T3 + PMA & 14.2 & $<2$ & 19.5 & 5.1 \\
\hline Ionomycin & $<2$ & $<2$ & $<2$ & $<2$ \\
\hline Ionomycin + PMA & 21.1 & $<2$ & 34.0 & 5.4 \\
\hline
\end{tabular}

Jurkat and HUT 78 were stimulated at $1 \times 10^{6} / \mathrm{ml}$ for $24 \mathrm{~h}$ using the following concentrations of stimulants: PMA, $50 \mathrm{ng} / \mathrm{ml}$, for Jurkat, 25 $\mathrm{ng} / \mathrm{ml}$ for HUT 78; PHA, $1 \mu \mathrm{g} / \mathrm{ml}$; anti-T3 (Leu 4), at a dilution of $1: 400$, ionomycin, $1 \mu \mathrm{M}$. Cultures were performed in parallel in the presence $(+\mathrm{CsA})$ or absence of cyclosporin $\mathrm{A}(-\mathrm{CsA})$ using a concentration of $1 \mu \mathrm{g} / \mathrm{ml}$. IL-2 activity in cell-free supernatants was determined as described in Methods.

* Figures are representative of three independent experiments and are expressed as IL-2 units per milliliter.

consistent IL-2 production induced by PMA alone is not affected by the presence of CsA. Furthermore, when HUT 78 cells exposed to CsA are stimulated with PHA or T3 antibodies plus PMA, the IL-2 production cannot be blocked completely, but is reduced to the amount observed with PMA only.

5-Azacytidine treatment increases PMA sensitivity of HUT 78 cells. AZA is a nucleoside analogue that in combination with a second stimulus can selectively activate eukaryotic gene expression (14-16). Therefore, we examined whether AZA pretreatment of HUT 78 cells had any influence on the two-signalinduced IL-2 gene activation in these cells. When HUT 78 cells were incubated with $3 \mu \mathrm{M}$ AZA for $72 \mathrm{~h}$ (with addition of fresh AZA after $48 \mathrm{~h}$ ), the requirement for PHA for the induction of IL-2 production could be overcome. The IL-2 production by HUT 78 after AZA treatment in response to PMA alone $(58.7 \pm 16.0 \mathrm{U} / \mathrm{ml})$ was comparable with the response observed with PHA plus PMA (58.2 $\pm 15.3 \mathrm{U} / \mathrm{ml})$.

Fig. 1 illustrates the effect of the duration of AZA preincubation on the IL-2 response of HUT 78 cells. The production of IL-2 induced by PHA plus PMA or PMA only after various AZA incubation periods is shown. An incubation period of 72 $\mathrm{h}$, with addition of fresh AZA after $48 \mathrm{~h}$, maximally increased the responsiveness of HUT 78 to PMA only. This time course probably reflects the requirement for the presence of AZA during

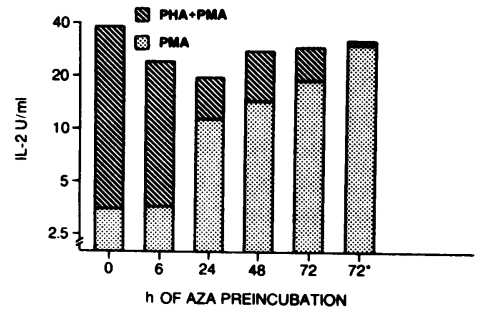

Figure 1. AZA-induced effect on IL-2 production by HUT 78 is dependent on the incubation period. HUT 78 cells were incubated for indicated time intervals with $3 \mu \mathrm{M}$ AZA. * Indicates the addition of fresh AZA after $48 \mathrm{~h}$. Thereafter, cells were washed and stimulated with $1 \mu \mathrm{g} / \mathrm{ml}$ PHA plus $25 \mathrm{ng} / \mathrm{ml}$ PMA or $25 \mathrm{ng} / \mathrm{ml} \mathrm{PMA} \mathrm{only.} \mathrm{IL-2}$ activity in cell-free supernatants was determined as described in Methods. 
several cycles of DNA synthesis and cell division. The average doubling time for HUT 78 in our experiments is $\sim 20 \mathrm{~h}$. The IL-2 production in response to different concentrations of PMA before and after AZA treatment is shown in Fig. 2. This shows that AZA preincubation increases the sensitivity of HUT 78 to PMA 20-50-fold both in the presence and absence of PHA. In this dose-response experiment, there was some low level constitutive IL-2 production detectable in AZA treated cells.

CsA does not block IL-2 production by AZA-treated HUT 78 clone $D 4$. In the following experiments, we cloned AZAtreated HUT 78 cells by limiting dilution (see Methods) and tested 11 clones for their sensitivity to PMA. 8 out of those 11 clones exhibited a similar increased PMA sensitivity, the highest in a clone designated D4, as described for the AZA-treated bulk culture cells. This functional characteristic of D4 proved to be stable in culture over several months.

The availability of this clone, which produced high levels of IL-2 in response to PMA, only allowed a more detailed investigation of the CsA effect on this pathway of activation. Fig. 3 shows that, in contrast to the wild type HUT 78, D4 cells produce almost identical amounts of IL-2 in response to PHA plus PMA as in response to PMA only. In addition, CsA did not show any inhibitory effect on the induction of IL-2 secretion in D4 by various concentrations of PMA. This is not simply due to an increased resistance to CsA, because even a 10-fold increased dose of CsA (10 $\mu \mathrm{g} / \mathrm{ml}$, the highest dose that did not produce

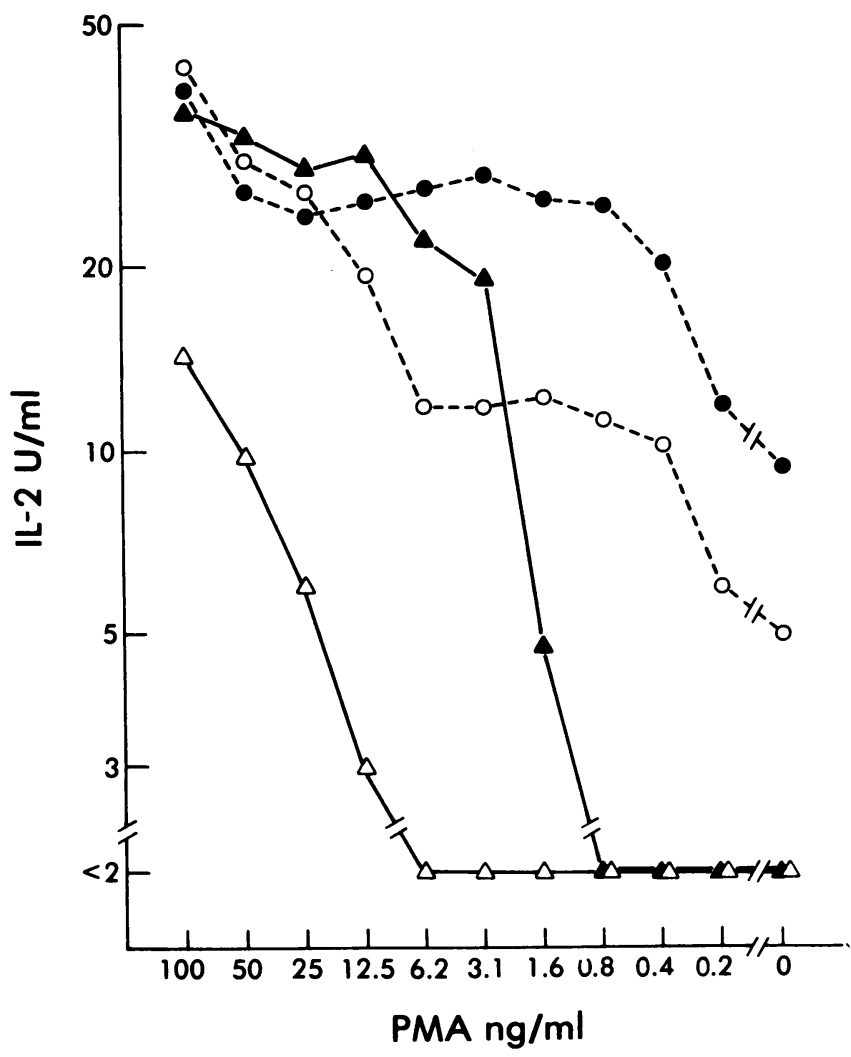

Figure 2. AZA treatment increases PMA sensitivity in HUT 78. HUT 78 cells were treated with $3 \mu \mathrm{M}$ AZA for $72 \mathrm{~h}$ as described with the addition of fresh AZA after $48 \mathrm{~h}$. After washing, cells were stimulated using indicated concentrations of PMA in the presence (๑) and absence (o) of $1 \mu \mathrm{g} / \mathrm{ml}$ PHA. The PMA dose-response of untreated HUT 78 cells in the presence $(\triangle)$ and absence $(\Delta)$ of PHA is shown for comparison.
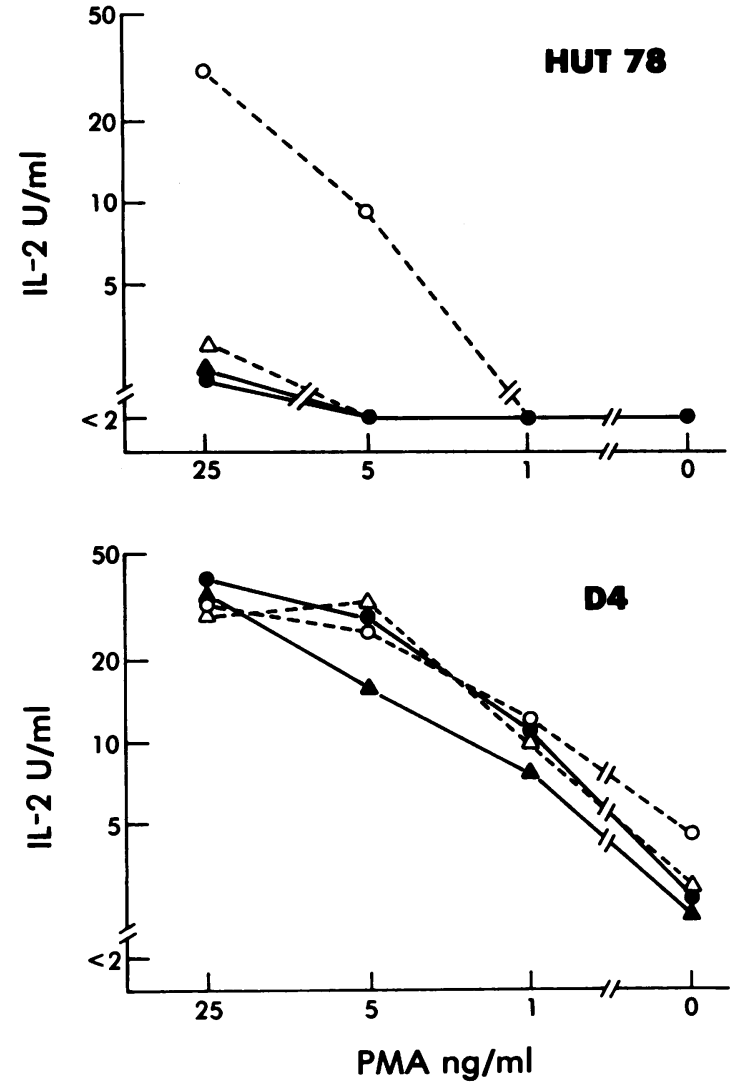

Figure 3. IL-2 production by D4 cannot be blocked by CsA. HUT 78 and D4 cells were stimulated at $1 \times 10^{6} / \mathrm{ml}$ using indicated concentrations of PMA in the presence and absence of $1 \mu \mathrm{g} / \mathrm{ml}$ PHA and 1 $\mu \mathrm{g} / \mathrm{ml}$ CsA, respectively. The different symbols represent: PHA

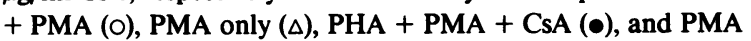
$+\operatorname{CsA}(\Delta)$.

direct toxic effects on D4) did not substantially reduce IL-2 production (data not shown).

It has recently been shown that the inhibition of lymphokine production by CsA represents an effect on a pretranslational event. When IL-2 specific transcripts were analyzed in a Northern blot, a small amount of IL-2 mRNA was detectable in unstimulated D4 cells (Fig. 4). PMA treatment markedly increased the appearance of transcripts, and no blocking effect could be observed in the presence of CsA. In parallel control experiments, the PHA/PMA-induced appearance of IL-2 mRNA in Jurkat could be completely blocked by the same concentration of CsA, in agreement with previously published data $(11,12)$. This again suggests that the PMA-induced pathway of $T$ cell activation is not affected by CsA.

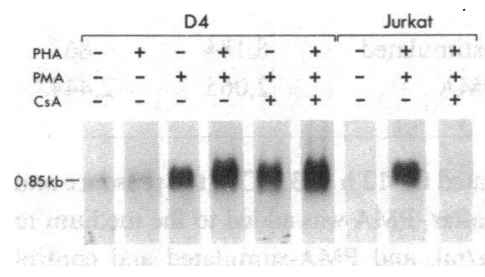

Figure 4. CsA does not inhibit the PMA-induced increase of IL-2-specific transcripts in D4. IL-2 cDNA was hybridized to total cellular RNA of D4 or Jurkat cells (40 $\mu \mathrm{g}$ per lane). Before RNA was isolated, cells were incubated for $6 \mathrm{~h}$ in

the presence $(+)$ and absence $(-)$ of indicated stimuli and CsA, respectively, using the following concentrations: PHA, $1 \mu \mathrm{g} / \mathrm{ml}$, PMA, 50 $\mathrm{ng} / \mathrm{ml}$, and CsA, $1 \mu \mathrm{g} / \mathrm{ml}$. 
CsA does not inhibit PMA-induced translocation of protein kinase $C$. It has recently been demonstrated that the enzyme protein kinase $\mathrm{C}(\mathrm{pkC})$ is one of the target structures for PMA and plays a crucial role in cell activation (22). This $\mathrm{Ca}^{++}$- and phospholipid-dependent enzyme, under resting conditions, is present in an inactive soluble form in the cytoplasm of cells. Upon stimulation with PMA, the pkC becomes activated and tightly associated with the plasma membrane (19). We therefore examined whether preincubation of Jurkat cells with CsA and the presence of CsA during a 20-min stimulation with PMA had any influence on pkC translocation. Whereas PMA induced a marked shift of pkC activity from the cytosol to the membrane fraction, CsA did not interfere with this early intracellular activation signal (Table II). This again supports the findings that CsA does not inhibit the PMA-induced pathway of T cell activation.

\section{Discussion}

We have studied stimulation requirements and intracellular signaling of $\mathrm{T}$ cell activation using human $\mathrm{T}$ cell lines as a model. IL-2 gene expression in Jurkat requires the combination of an increase in $\left[\mathrm{Ca}^{++}\right]_{i}$ and the presence of PMA $(9,10)$. The synergism of these signals also induces maximal IL-2 production in another T cell line, HUT 78. In contrast to Jurkat, however, low levels of IL-2 in HUT 78 are induced by PMA only, and small amounts of IL-2 transcripts can be detected even in the resting state (23).

To obtain further information about the intracellular mechanisms leading to IL-2 gene expression we investigated the effect of AZA in this system. AZA, a cytidine analogue, has been shown to selectively activate eukaryotic gene expression in a variety of systems (i.e., mouse metallothionein, chicken embryonic globin, and human DR alpha). In these experiments, AZA treatment, presumably causing DNA hypomethylation, provided one signal which together with another stimulus (i.e., dexamethasone, butyrate, and $\gamma$-IFN, respectively) induces activation of transcriptionally inactive genes (14-16). In HUT 78, AZA treatment could overcome the requirement for $\left[\mathrm{Ca}^{++}\right]_{\mathrm{i}}$ increasing stimuli in the induction of IL-2 production. In AZA-treated HUT 78, maximal production of IL-2 could be induced by PMA only. This might be due to $(a)$ A demethylation event in a regulatory element of the IL-2 gene itself, by which the requirement for a

Table II. Cyclosporin A Does Not Inhibit

PMA-Induced Translocation of Protein Kinase C

\begin{tabular}{lllr}
\hline & & Cytosol & Membrane \\
\hline Untreated cells & Unstimulated & $8,320^{*}$ & 938 \\
& +PMA & 1,616 & 2,239 \\
12-h CsA incubation & Unstimulated & 8,184 & 867 \\
& +PMA & 2,065 & 2,444
\end{tabular}

$1 \times 10^{7} \mathrm{Jurkat}$ cells were incubated for $12 \mathrm{~h}$ at $37^{\circ} \mathrm{C}$ in the presence and absence of $1 \mu \mathrm{g} / \mathrm{ml} \mathrm{CsA}$. Thereafter, PMA was added to the medium to a final concentration of $50 \mathrm{ng} / \mathrm{ml}$, and PMA-stimulated and control cultures were incubated for another $20 \mathrm{~min}$. After washing, cells were lysed and protein kinase $\mathrm{C}$ activity in the cytosol and membrane fractions determined as described in Methods.

* Figures give picomoles ${ }^{32} \mathrm{P}$-incorporation into histone per $3 \mathrm{~min}$.
$\left[\mathrm{Ca}^{++}\right]_{\mathrm{i}}$-induced activation signal is bypassed; $(b)$ The transcription of a protein with regulatory function in activation signaling might be increased by AZA, thus bypassing the need for a rise in $\left[\mathrm{Ca}^{++}\right]_{i} ;(c)$ Selective gene activation induced by AZA might occur on a level different from methylation events altogether, because methylation is obviously not the only factor governing gene expression and AZA has a broad spectrum of effects on a variety of cells (24).

Finally, yet another possibility could account for the observed increased PMA sensitivity in HUT 78 after AZA treatment. If HUT 78 was comprised of distinct subpopulations of different PMA sensitivity, selective killing of a major percentage of cells with low PMA sensitivity could lead to the observed effect. Although this cannot be ruled out entirely, it appears unlikely, because under the described conditions AZA incubation slowed down cell growth but did not have any substantial effect on cell viability. In the subsequent experiments we were able to culture a subclone with a high response to PMA alone from AZA-treated HUT 78 cells, designated D4. It maintained this functional characteristic in long-term culture.

The availability of these $T$ cell lines with different stimulation signal requirements enabled us to analyze the inhibitory mechanisms of CsA in T cell activation. CsA, a potent immunosuppressive agent, inhibits the production of lymphokines by activated T cells (4-6). When added to PHA/PMA-stimulated Jurkat, CsA prevents the appearance of transcripts for IL-2 and $\gamma$-IFN $(11,12)$. CsA, therefore, clearly affects events during $T$ cell activation that occur before the translation of lymphokine genes. However, from these studies it is not clear which pathway of activation signaling is affected by CsA.

Additional information was obtained by investigating the CsA effect on HUT 78. The addition of CsA to HUT 78 had no effect on the response to PMA alone, but completely inhibited the synergistic effects with agents that increase $\left[\mathrm{Ca}^{++}\right]_{\mathbf{i}}$ (PHA, T3-antibodies, or ionomycin). In addition, maximal IL-2 production induced by PMA in the AZA-treated HUT 78 subclone D4 was not blocked by CsA. Furthermore, as has been reported with other models of $\mathrm{T}$ cell activation, CsA has no effect on the ability of PMA alone to induce the expression of IL-2 receptors in HUT 78 (11; data not shown). Finally, CsA does not inhibit translocation and activation of pkC, which is known to be one of the primary targets for PMA (22). These findings suggest that CsA does not affect signaling pathways that are controlled by PMA alone. Thus, the CsA-sensitive step in $T$ cell activation signaling can be $(a)$ part of a pathway regulated by $\left[\mathrm{Ca}^{++}\right]_{\mathrm{i}}$ alone, or $(b)$ regulated by $\left[\mathrm{Ca}^{++}\right]_{i}$ and PMA at a later stage after these two pathways converged.

CsA does not prevent lectin- or antigen-mediated increases in $\left[\mathrm{Ca}^{++}\right]_{i}$, and $\mathrm{CsA}$ induced inhibition cannot be overcome with $\mathrm{Ca}^{++}$ionophores $(12,25)$. The effect of $\mathrm{CsA}$, then, is on pathways distal to the increase in $\left[\mathrm{Ca}^{++}\right]_{\mathrm{i}}$ and not on the initial, plasma membrane-associated events in activation. Many intracellular $\mathrm{Ca}^{++}$-dependent events are in turn regulated by the $\mathrm{Ca}^{++}$ binding protein, calmodulin. Of considerable interest is the demonstration by Colombani et al. (26) that CsA binds to calmodulin and inhibits calmodulin-dependent phosphodiesterase activity in vitro. Although inhibition of a specific $\mathrm{Ca}^{++}$-calmodulin regulated event in $\mathrm{T}$ cell activation signaling is an attractive explanation for the inhibitory effects of CsA, CsA also binds to cyclophilin, a cytosolic protein whose function is unknown (27).

As previously reported, HUT 78 represents, compared with Jurkat, a T cell on a higher activation level (13). This also reflects 
in the fact that HUT 78 (and D4), in contrast to Jurkat, produce low levels of IL-2-specific transcripts even without stimulation. Therefore, it is possible that CsA blocks only the $\left[\mathrm{Ca}^{++}\right]_{\mathrm{i}}$ and PMA-regulated de novo expression of the IL-2 gene in Jurkat, but has no influence on the "PMA only"-induced enhancement of the appearance of IL-2 mRNA in HUT 78 or D4.

In contrast to the findings reported here are studies using the mouse thymoma cell line EL4. This cell line can be induced to produce IL-2 by PMA alone (28), and this induction is blocked by CsA on the level of mRNA $(29,30)$. This might support the possibility that $\mathrm{CsA}$ inhibits a later signaling step after the $\left[\mathrm{Ca}^{++}\right]_{i-}$ and PMA-regulated pathways have converged. Activation signaling in EL4 cells, however, appears to be different from the cell lines reported in this study because we did not observe any increase in $\left[\mathrm{Ca}^{++}\right]_{\mathrm{i}}$ in EL4 upon stimulation with lectins or antigen receptor antibodies (Weiss, A., unpublished observations). What the differences are in activation signaling between EL4 and the cell lines used in this study remains to be elucidated.

Although the experiments reported here were performed using $T$ cell lines as models for $T$ cell activation, similar observations have been made for human $T$ lymphocytes from peripheral blood. Accessory cell-depleted $\mathrm{T}$ cells showed a moderate proliferative response to PMA, which was only slightly reduced in the presence of CsA (6). Furthermore, Britton and Palacios described a human $\mathrm{T}$ cell clone in which activation induced by PMA only was not inhibited by CsA (31).

In summary, our studies demonstrate that the inhibitory effect of CsA is not a global blockade of IL-2 gene expression. Despite considerable recent progress in understanding the mechanism of $T$ cell activation, little is known about the intracellular pathways that regulate lymphokine gene expression. It is of interest, then, that CsA selectively inhibits a pathway that requires an increase in $\left[\mathrm{Ca}^{++}\right]_{i}$. Thus, CsA may be a useful tool for further characterization of intracellular pathways in $T$ cell activation.

\section{Acknowledgments}

The authors wish to thank Dr. Wayne Anderson for his help and advice with the protein kinase $\mathrm{C}$ assay and Dr. John Imboden for stimulating discussions. The skillful technical assistance of Mr. Robert Atchison is gratefully acknowledged.

This work was supported by the Deutsche Forschungsgemeinschaft grant Ma 986/1-1 to Dr. Manger, by U. S. Public Health Service grant AI 14104, and by Arthritis and Metabolic Diseases Training grant AM07304. Dr. Weiss and Dr. Hardy are assistant investigators of the Howard Hughes Medical Institute.

\section{References}

1. Borel, J. F., C. Feurer, C. Magnee, and H. Stahelin. 1977. Effects of the new antilymphocytic peptide cyclosporin A in animals. Immunology. 32:1017-1025.

2. Larsson, E.-L. 1980. Cyclosporin A and dexamethasone suppress $\mathrm{T}$ cell responses by selectively acting at distinct sites of the triggering process. J. Immunol. 124:2828-2833.

3. Shevach, E. M. 1985. The effects of cyclosporin A on the immune system. Ann. Rev. Immunol. 3:397-423.

4. Bunjes, D., C. Hardt, M. Röllinghoff, and H. Wagner. 1981. Cyclosporin A mediates immunosuppression of primary cytotoxic T-cell responses by impairing the release of interleukin 1 and interleukin 2 . Eur. J. Immunol. 11:657-661.

5. Hess, A. D., P. J. Tutschka, Z. Pu, and G. W. Santos. 1982. Effect of cyclosporin A on human lymphocyte responses in vitro. IV. Production of $\mathrm{T}$ cell stimulatory growth factors and development of responsiveness to these growth factors in CsA-treated primary MLR cultures. J. Immunol. 128:360-367.

6. Reem, G. H., L. A. Cook, and J. Vilcek. 1983. Gamma interferon synthesis by human thymocytes and $T$ lymphocytes inhibited by cyclosporin A. Science (Wash. DC). 221:63-65.

7. Miyawaki, T., A. Yachie, S. Ohzeki, T. Nagaoki, and N. Taniguchi. 1983. Cyclosporin A does not prevent expression of Tac antigen, a probable TCGF receptor molecule, on mitogen-stimulated human T cells. $J$. Immunol. 130:2737-2742.

8. Lillehoj, H. S., T. R. Malek, and E. M. Shevach. 1984. Differential effect of cyclosporin $A$ on the expression of $T$ and $B$ lymphocyte activation antigens. J. Immunol. 133:244-250.

9. Weiss, A., J. Imboden, D. Shoback, and J. Stobo. 1984. Role of T3 surface molecules in human $T$ cell activation: $T 3$-dependent activation results in an increase in cytoplasmic free calcium. Proc. Natl. Acad. Sci. USA. 81:4169-4173.

10. Weiss, A., R. L. Wiskocil, and J. D. Stobo. 1984. The role of T3 surface molecules in the activation of human $T$ cells: a two stimulus requirement for $\mathrm{IL}-2$ production reflects events occuring at a pre-translational level. J. Immunol. 133:123-128.

11. Krönke, M., W. J. Leonard, J. M. Depper, S. K. Arya, F. WongStaal, R. C. Gallo, T. A. Waldmann, and W. C. Greene. 1984. Cyclosporin A inhibits T-cell growth factor gene expression at the level of mRNA transcription. Proc. Natl. Acad. Sci. USA. 81:5214-5218.

12. Wiskocil, R., A. Weiss, J. Imboden, R. Kamin-Lewis, and J. Stobo. 1985. Activation of a human $T$ cell line: a two-stimulus requirement in the pretranslational events involved in the coordinate expression of interleukin 2 and $\gamma$-interferon genes. J. Immunol. 134:1599-1603.

13. Manger, B., A. Weiss, C. Weyand, J. Goronzy, and J. D. Stobo. 1985. T cell activation: differences in the signals required for IL-2 production by non activated and activated T cells. J. Immunol. 135:36693673.

14. Compere, S. J., and R. D. Palmiter. 1981. DNA methylation controls the inducibility of the mouse metallothionein-I gene in lymphoid cells. Cell. 25:233-240.

15. Ginder, G. D., M. J. Whitters, and J. K. Pohlman. 1984. Activation of a chicken embryonic globin gene in adult erythroid cells by 5azacytidine and sodium butyrate. Proc. Natl. Acad. Sci. USA. 81:39543958.

16. Peterlin, B. M., T. A. Gonwa, and J. D. Stobo. 1984. Expression of HLA-DR by a human monocyte cell line is under transcriptional control. J. Mol. Cell. Immunol. 1:191-200.

17. Gillis, S., M. Ferm, W. Ou, and K. Smith. 1978. T cell growth factor: parameters of production and a quantitative microassay for activity. J. Immunol. 120:2027-2032.

18. Cheley, S., and R. Anderson. 1984. A reproducible microanalytical method for the detection of specific RNA sequences by dot-blot hybridization. Anal. Biochem. 137:15-19.

19. Kraft, A. S., and W. B. Anderson. 1983. Phorbol esters increase the amount of $\mathrm{Ca}^{++}$, phospholipid-dependent protein kinase associated with plasma membrane. Nature (Lond.). 301:621-623.

20. Kraft, A. S., W. B. Anderson, H. L. Cooper, and J. J. Sando. 1982. Decrease in cytosolic calcium/phospholipid-dependent protein kinase activity following phorbol ester treatment of EL4 thymoma cells. J. Biol. Chem. 257:13193-13196.

21. Imboden, J., A. Weiss, and J. D. Stobo. 1985. The antigen receptor on a human $\mathrm{T}$ cell line initiates activation by increasing cytoplasmic free calcium. J. Immunol. 134:663-665.

22. Nishizuka, Y. 1984. The role of protein kinase $C$ in cell surface signal transduction and tumour promotion. Nature (Lond.). 308:693698.

23. Manger, B., A. Weiss, K. J. Hardy, and J. D. Stobo. 1986. A transferrin receptor antibody represents one signal for the induction of IL 2 production by a human T cell line. J. Immunol. 136:532-538.

24. Jones, P. A. 1985. Altering gene expression with 5-azacytidine. Cell. 40:485-486. 
25. Metcalf, S. 1984. Cyclosporine does not prevent cytoplasmic calcium changes associated with lymphocyte activation. Transplantation. 38:161-164.

26. Colombani, P. M., A. Robb, and A. D. Hess. 1985. Cyclosporin A binding to calmodulin: a possible site of action on $\mathrm{T}$ lymphocytes. Science (Wash. DC). 228:337-339.

27. Handschumacher, R. E., M. W. Harding, J. Rice, and R. J. Drugge. 1984. Cyclophilin: a specific cytosolic binding protein for cyclosporin A. Science (Wash. DC). 226:544-547.

28. Farrar, J. J., J. Fuller-Farrar, P. L. Simon, M. L. Hilfiker, B. M.
Stadler, and W. L. Farrar. 1980. Thymoma production of T cell growth factor (interleukin 2). J. Immunol. 125:2555-2558.

29. Elliot, J. F., Y. Lin, S. B. Mizel, R. C. Bleackley, D. G. Harnish, and V. Paetkau. 1984. Induction of interleukin 2 messenger RNA inhibited by cyclosporin A. Science (Wash. DC). 226:1439-1441.

30. Granelli-Piperno, A., K. Inaba, and R. Steinman. 1984. Stimulation of lymphokine release from $\mathrm{T}$ lymphoblasts. Requirement for mRNA synthesis and inhibition by cyclosporin A. J. Exp. Med. 160: 1792-1802.

31. Britton, S., and R. Palacios. 1982. Cyclosporin A-usefulness, risks, and mechanism of action. Immunol. Rev. 65:5-22. 